$10.14324 / 111.2052-1871.119$

\title{
PRIVATE PRISON LABOUR: PARADOX OR POSSIBILITY? EVALUATING MODERN-DAY SYSTEMS AND ESTABLISHING A MODEL FRAMEWORK THROUGH THE LENS OF THE FORCED LABOUR CONVENTION
}

Mario Guido*

\begin{abstract}
Overcrowding, deteriorating conditions, ever-increasing costs, recidivism. These are the terms that come to mind when thinking of the world's punitive justice systems. Ostensibly, the international community has set out to combat these issues and it would be incorrect to say that measures in that direction have not been taken. Nonetheless, certain states have sought to remedy reoffending and favour reinsertion by increasing employment opportunities for prisoners and delegating the task to the private sector. In some common law jurisdictions, prisons have been entirely privatised ('wholesale' approach) whereas civil law jurisdictions tend to only privatise specific services while custodial functions remain with the State ('semiprivée' system). Regardless, given that France, Germany, and Australia have adopted these practices despite adoption of the Forced Labour Convention of the International Labour Organisation, which prima facie precludes private prison labour, it is thus necessary to analyse the reasons for these developments and to evaluate these systems. This article identifies the French system as the most compatible with the Convention and proposes a model framework that complies with the norm and serves the objectives of modern penal systems.
\end{abstract}

\section{A. INTRODUCTION}

Our continuous use of imprisonment as punishment has led us to a situation characterised by overcrowded prisons, unsustainable schemes, and unacceptable conditions in many penal systems around the globe. It is therefore unsurprising to find high recidivism rates in several states. As a response, and in accordance with economic trends, several governments have delegated prison management to private enterprises in the hope of gradually solving such issues. Yet, as members of the International Labour Organisation (hereafter 'ILO'), France, Germany, and Australia have agreed to abide by their international obligations with respect to labour rights. In addition to having distinct legal traditions in terms of criminal justice and labour law, these jurisdictions have all been subject to comments by the ILO in relation to the employment of prisoners by private entities.

In this article, I argue that in designing a system of private prison labour, compliance with the requirements of the Forced Labour Convention is a necessary first step to avoid the exploitation of prisoners and to protect human rights. In order to achieve the further objective of reducing recidivism through this system, the framework presented in the convention ought

\footnotetext{
* LL.M. (University College London), LL.B. with Legal Studies in Europe (University of Reading, Uppsala University, University of Geneva), Certificate in Transnational Law (University of Geneva).
} 
to be emulated and further developed. The analysis will focus on the manner in which states have accommodated this practice and evaluate whether they have successfully complied with the international standard, in order to subsequently create a model that not only respects the Convention, but also encourages social rehabilitation and reinsertion. In order to do this, Section B will explore the origins and the evolving objectives of prison labour as well as the context in which prison and prison labour privatisation were undertaken by states. Section $\mathrm{C}$ will then address, the requirements of the Forced Labour Convention in order to transpose them onto the situations in France, Germany, and Australia in Section D. The choice of these jurisdictions is due to their distinct legal traditions and the fact that I was aware from previous studies in the area that the topic had been discussed at the ILO. Finally, Section E will determine the most compatible system with the Convention and offer a legally compliant framework for future prison labour privatisation. It is clear that private sector involvement in the penitentiary system was intended, inter alia, to provide better rehabilitation and reinsertion opportunities and to ameliorate prison conditions. However, decades later, the systems erected remain in contravention of the Convention and might fall short of their objectives. Overall, although deficient as regards the Convention requirement of 'public supervision and control', the French system remains the closest to the international standard and is the most protective of human rights.

\section{B. PRISON LABOUR AND PRIVATISATION}

Understanding the evolution in the objectives of prison labour, the context, and the reasons behind the worldwide trend in the whole or partial privatisation of the criminal justice system is crucial prior to entering a discussion on its contemporary merits.

\section{Prison labour}

Prison labour has been employed for centuries, although its aims seem to have evolved over time. As a measure it is inherently controversial, ${ }^{1}$ and several questions emerge from its use, for example Feldman asks: 'what role does prison labour serve? (...) Can prison labour ever be voluntary, or is it always an act of state coercion?'. ${ }^{2}$ Critics point out 'the exploitative nature of such labour and [hint] that large profits may be squeezed out from those who are unable to resist the might of the

\footnotetext{
${ }^{1}$ Dirk van Zyl Smit and Frieder Dünkel, Prison Labour: Salvation or Slavery? (Ashgate Dartmouth 1999) VII.

2 Lindsey Raisa Feldman 'Prison Labour' (Oxford Bibliographies, 2018) <http://www.oxfordbibliographies.com/view/document/obo-9780195396607/obo-9780195396607-0236.xml> accessed on 28 June 2018.
} 
State that backs the prison authorities'. ${ }^{3}$ However, some commentators argue that prison labour serves a rehabilitative purpose and can reduce recidivism rates while others maintain that it can provide a source of profit if appropriately implemented. ${ }^{4}$ Most importantly, in recent times, arguments that prison labour can achieve both these objectives have surfaced. Richardson's observation that the rights of prisoners vary according to the purpose which imprisonment serves, seems to be applicable to prison labour ${ }^{5}$ in that its nature will alter depending on its objective. Thus, as prisoners are 'sent [to prison] as punishment [and] not for punishment', ${ }^{6}$ prison labour should not serve as a deterrent or as a punishment, but rather as a means of reformation and social reinsertion. This formulation is not incompatible with the proposal that prison labour should provide profit for either public or private interests. Nevertheless, it may give rise to moral and legal implications that will be further examined in this article.

\section{a) Origins}

As originally conceived, prison labour was mainly employed as a tool for punishment around the world. For instance, hard labour amounted to the penal element of a sentence in England and Wales in the nineteenth century. ${ }^{7}$ The Hard Labour Act 1822, the 1865 Prison Act creating a regime of hard pointless labour, and the Du Cane era $(1869-1895)^{8}$ cemented the concept of prison labour as a punishment based upon the ideas of deterrence and retribution. Until the abolition of hard labour without purpose through the Prison Act 1898, strenuous activities such as the penal treadmill or the crank were widely employed in England and Wales. ${ }^{9}$ Throughout history, prison labour has appeared via colonization or in situations of war. ${ }^{10}$ In fact, 'in colonial settings, penal servitude was an integral part of [the] system'. ${ }^{11}$ Overall, in Europe, forced prison labour gained popularity

\footnotetext{
${ }^{3}$ van Zyl Smit and Dünkel (n 1).

${ }^{4}$ ibid.

5 Genevra Richardson, 'The Case for Prisoners' Rights' in Mike Maguire, Rod Morgan and Jon Vagg (eds), Accountability and Prisons: Opening up a Closed World (Tavistock Publications 1985) 22.

${ }^{6}$ Ian O'Donnell, 'The aims of imprisonment' in Yvonne Jewkes, Jamie Bennett and Ben Crewe (eds), Handbook on Prisons (2nd edn, Routledge 2016) 45.

7 Victor Bailey, 'English Prisons, Penal Culture, and the Abatement of Imprisonment: 1895-1922' (1997) 36(3) Journal of British Studies 285, 295.

${ }^{8}$ Sean McConville, 'The Victorian Prison' in Norval Morris and David J. Rothman (eds), The Oxford History of the Prison: The Practice of Punishment in Western Society (OUP1998) 138.

9 Encyclopaedia Britannica, 'Britannica on the treadmill' Encyclopaedia Britannica (13th edn) <https://www.britannica.com/topic/Britannica-on-the-treadmill-1998450\#ref1205851> accessed on 29 June 2018.

${ }^{10}$ Christian G. De Vito and Alex Lichtenstein, 'Writing a Global History of Convict Labour' (2013) 58 International Review of Social History 285, 291.

11 ibid 298.
} 
from the sixteenth century onwards. ${ }^{12}$ Interestingly, there were already instances, where prisoners were entrusted to private employers. For example, in 'Spanish America, prisoners sentenced to hard labour by the colonial courts were also leased to private employers who used them in mines, manufactures, and mills'. ${ }^{13}$ Thus, although the arrangements as well as the nature of the work imposed changed, prison labour along with the employment of prisoners for private benefit, are aged concepts.

\section{b) Objectives}

For the purposes of this article, the rehabilitative and financial objectives are of interest.

i) Rehabilitation and reinsertion

The idea of rehabilitation refers to the provision of 'opportunities for prisoners to obtain knowledge and skills that can assist them in their successful reintegration upon release, with a view to avoiding future offending'. ${ }^{14}$ In 1932, the international community recognised that the process of rehabilitation was 'precisely the aim of modern penal systems'. ${ }^{15}$ To achieve this objective, states compel or offer employment opportunities to prisoners as prison labour has been identified as a key factor in reducing re-offending. ${ }^{16}$ Although at the time of drafting the Convention Concerning Forced or Compulsory Labour 1930 (No. 29) of the ILO prison labour was still based upon the principle of retribution and deterrence, it was recognised that another 'aim of employing the prisoner on instructive and useful work is to strengthen his moral character during the period of detention and make him capable of living a straight and regular life' ${ }^{17}$ In fact, employment is a vital element of a successful life and it 'provides individuals with financial independence, a sense of self-worth, community involvement, satisfaction, status, and belonging'. ${ }^{18}$ Practically, prison labour 'has the potential to provide important job skills that might be useful for prisoners in seeking employment after their release. Regular participation in work

\footnotetext{
${ }^{12}$ Pieter Spierenburg, 'The Body and the State: Early Modern Europe' in Norval Morris and David J. Rothman, (eds), The Oxford History of the Prison: The Practice of Punishment in Western Society (OUP 1998) 46.

${ }^{13}$ De Vito and Lichtenstein (n 10).

${ }^{14}$ United Nations Office on Drugs and Crime, Roadmap for the development of prison-based rehabilitation programmes (United Nations Office at Vienna, 2017) 1.

${ }^{15}$ International Labour Organisation, 'Prison Labour I' (1932) 25 International Labour Review 311, 314.

${ }^{16}$ Social Exclusion Unit, 'Reducing re-offending by ex-prisoners' (Office of the Deputy Prime Minister, July 2002) 6.

${ }^{17}$ International Labour Organisation, 'Prison Labour II' (1932) 25 International Labour Review 499, 522.

${ }^{18}$ The Howard League for Penal Reform, 'Prison, work and social enterprise: the story of Barbed' (Esmée Fairbairn Foundation, 2008) 11.
} 
can also help to inculcate prisoners with more disciplined work and personal habits' ${ }^{19}$ In 2005 , Shea found that few prisoners were actually employed: 46.5 per cent in France and 53.6 per cent in Germany. ${ }^{20}$ As it became clear that the prison service in these states was unable to accommodate sufficient employment opportunities for inmates, they were 'forced to turn increasingly to outside companies'. ${ }^{21}$ In Australia, there are also 'more prisoners than jobs available'. ${ }^{22}$

ii) Financial objective

Prison labour can also help defray the costs of incarceration and be a source of cheap labour. Fenwick notes 'the generation of money is another important factor of inmate labour'. ${ }^{23}$ Due to the high costs of incarceration, prisoners may be employed for the general 'upkeep and running of a prison: laundry, kitchens, maintenance, and the like, ${ }^{24}$ as well as in prison industries which may include some involvement by private entities. ${ }^{25}$ Those in favour of private-entity involvement in prison labour have argued that prisons could turn into a profit-making enterprise. ${ }^{26}$ However, in my view, as it is not always the case that the most profitable work carries the highest rehabilitative value, 'partnership projects with private companies must be strictly regulated to avoid the charge of exploitation'. ${ }^{27}$ The tension 'between the reformative aims of the State and the business interests of private entities ${ }^{28}$ could imperil the attainment of the former. Yet, several states, including Australia, have argued that 'private sector involvement was needed in order to provide meaningful work for prisoners ${ }^{29}$ and to increase the amount of prisoners employed. Furthermore, while the question surrounding profit from prison industries remains subject to arrangements between states and the private entities themselves, it is clear that a perverse incentive has arisen. As put by Reverend Dr Peter Selby 'if numbers in prisons need to be reduced (...) is it helpful to create an interest in their growth among companies and their shareholders?' ${ }^{30}$

\section{c) Privatisation}

\footnotetext{
${ }^{19}$ Colin Fenwick, 'Private Use of Prisoners Labour: Paradoxes of International Human Rights Law' (2005) 27(1) Hum.Rts.Q. 249, 261.

${ }^{20}$ Evelyn Shea, 'A Comparative Study of Prison Labour in France, Germany and England' [2005] Penal Issues 11.

21 ibid 12.

22 Rob White, 'On Prison Labour' (1999) 11(2) Current Issues in Criminal Justice 243, 245.

${ }^{23}$ Colin Fenwick, 'Regulating Prisoners' Labour in Australia: a Preliminary View' [2003] AJLL $284,303$.

${ }^{24}$ Fenwick, 'Private Use of Prisoners Labour' (n 19) 261.

25 ibid.

${ }^{26}$ Lisa C. Phelan, 'Making Prisons Work' (1997) 30 Loy.L.A.L.Rev. 1747, 1754.

27 The Howard League for Penal Reform, 'Rehabilitating Work: What are Prison Workshops For?' (London, 2000$) 3$.

${ }^{28}$ International Labour Organisation, 'Prison Labour I' (n 15) 321.

${ }^{29}$ International Labour Organisation, Report of the CEACR, Report III (Part 1A), ILC 90th Session, (2002), 97, [9].

${ }^{30}$ Prison Reform Trust, 'Private Punishment: Who Profits?' (London 2005) 1.
} 
Logan defines privatization as the 'transfer of assets, and of the production of public goods and services, from government to the private sector'. ${ }^{31}$ Henceforth, prison privatization can entail the 'construction, ownership, management [of prisons], prison industrial workshops, or specific services such as cleaning, maintenance, or court escort ${ }^{32}$ for a set period of time. States such as France and Germany have entered into public-private partnerships in which 'contractual specifications make it clear that the subcontractor [may be] (...) responsible for the general maintenance of the buildings, heating, food for prisoners, medical care, and for prisoners' labour'. ${ }^{33}$ On the other hand, in Australia and the UK, prison privatisation 'usually refers to the full package of services required in a prison'. ${ }^{34}$ Moreover, even though the movement towards prison privatisation began around the 1980s, at a time where neo-liberal ideology was flourishing, 'for-profit prison privatisation (...) dates back to sixteenth-century England' ${ }^{35}$ Several factors acted as catalysts in this return to private sector involvement in penitentiaries around the globe. Harding suggests that inter alia, the increases in prison population, overcrowding, deteriorating prison conditions and concerns about growing costs led states to return to private arrangements. ${ }^{36}$ Although 'the style of privatisation or its delivery method vary considerably depending on the country and its ongoing experience with privatization', ${ }^{37}$ most states reverted back to prison privatisation for similar reasons to the ones mentioned above.

Still, more than an alternative to public prison management, proponents of prison privatisation maintain that private entities are more innovative and reform minded than the public sector ${ }^{38}$ and 'provide a better service (...) at a lower cost' ${ }^{39}$ The concept of private prisons is part of a 'broader economic ideology, where the private sector and its natural competitive form are seen as an alternative to government service industry'. ${ }^{40}$ It was and is thought that since the private sector operates under the incentive of profit-making and is subject to competition, it would strive

\footnotetext{
${ }^{31}$ Charles Logan, Private Prisons: Cons \& Pros (OUP 1990) 3-4.

32 Bob Semmens, 'The Public / Private Dilemma in Australia' (1996) 47(2) Journal of Correctional Education $86,87$.

${ }^{33}$ Philippe Combessie, 'France' in Dirk van Zyl Smit and Frieder Dünkel (eds) Imprisonment Today and Tomorrow: International Perspectives on Prisoners' Rights and Prison Conditions (2nd edn, Kluwer Law International 2001) 256.

34 John Rynne and Richard Harding, 'Private Prisons' in Yvonne Jewkes, Jamie Bennett and Ben Crewe (eds), Handbook on Prisons (2nd edn, Routledge 2016) 150.

${ }^{35}$ Cody Mason, 'International Growth Trends in Prison Privatisation' (The Sentencing Project, Washington 2013 ) 1.

${ }^{36}$ Richard Harding, 'Private Prisons' (2001) 28 Crime and Justice 265, 269.

${ }^{37}$ Rynne and Harding (n 34) 153.

${ }^{38}$ Prison Reform Trust (n 30) 8.

39 Julian Le Vay, Competition for Prisons: Public or Private? (Policy Press 2016) 105.

40 Jesuit Social Services, Outsourcing Community Safety: Can private prisons work for public good? (2017) 2.
} 
to offer the best possible service at the lowest possible cost, without disproportionate cost-cutting measures that would compromise the quality of service. In contrast however, Mason argues persuasively that private prisons 'perform no better than publicly operated facilities, are not guaranteed to reduce correctional costs, and provide an incentive for increasing correctional and detention populations'. ${ }^{41}$ In truth, placing economic interests on the growth of the prison population seems counter-intuitive when the objective of prison services is to avoid re-offending and reduce the prison population. In my opinion, although private prisons have not themselves caused mass incarceration, Selman and Leighton are correct in pointing out that 'they [private prisons] were born of a fundamentally unjust incarceration, and they require the continuation of those dynamics in order to grow in their current form'. ${ }^{42}$

\section{d) A global trend?}

During Jacques Chirac's time as Prime Minister, a wave of privatisation swept through France, engulfing the prison service in a wider process of reform. The 1987 legislation ${ }^{43}$ enabled the private sector to be entrusted with all penal functions save for the supervision, control and security of inmates. The programme aimed to create 13,000 new prison spaces in the form of twenty-five new prisons. ${ }^{44}$ The change was partly motivated by the idea of modernising the prison service as well as increasing the amount of spaces available and improving conditions, all while lowering the costs of incarceration. ${ }^{45}$ However, unlike other jurisdictions, privatisation in France would only be partial and lead to the creation of, as termed by Harding, 'semi-privées'46 institutions, in other words a public-private partnership. As previously mentioned, under this approach, the 'custodial functions remain with the State while support services are tendered through contracts' ${ }^{47}$ In return for the provision of heating, catering, healthcare, labour for prisoners, and general maintenance, the subcontractor is paid a per diem rate per prisoner. ${ }^{48}$ In order to generate profit, the private entity can reduce 'the cost of services to prisoners [or even charge] companies a higher rate for prison labour than the cost of prisoners' salary'. ${ }^{49}$

\footnotetext{
${ }^{41}$ Mason (n 35) 11.

${ }^{42}$ Donna Selman and Paul Leighton, Punishment for Sale: Private Prisons, Big Business, and the Incarceration Binge (Rowman \& Littlefield Publishers 2010) 6.

${ }^{43}$ Loi n ${ }^{\circ} 87-432$ du 22 Juin 1987 relative au Service Public Pénitentiaire.

${ }^{44}$ Combessie (n 33) 255.

45 ibid 256.

${ }^{46}$ Harding (n 36) 274.

${ }^{47}$ Rynne and Harding (n 34) 153-54.

${ }^{48}$ Combessie (n 33) 256.

49 ibid.
} 
The 'wholesale' approach, initially adopted in the UK as well as in Australia and the United States of America (hereafter 'USA'), in which private entities build and run prisons wholly, was also rejected in Germany ${ }^{50}$ in favour of a 'semi-privée' management system. While criminal and prison law 'is a matter of federal competence, the prison administration and day-to-day running of prisons are the responsibility of federal states'. ${ }^{51}$ Furthermore, 'the first prison built by a private company was opened in 1996 in Waldeck near Rostock in the eastern part of Germany, while the private management of prisons was only started in this century'. ${ }^{2}$ Nonetheless, German constitutional law places limits upon which functions of the state may be delegated to private enterprises. ${ }^{53}$ Thus, although similar to the French model, German prison privatisation has not been as extensive. To date, private entities operate in five prisons in four different states and in the case of the Waldeck Prison, the private entity built and subsequently leased the institution to the state. ${ }^{54}$ Due to the constitutional requirement that 'sovereign powers' be entrusted to public civil servants, ${ }^{55}$ 'private contractors do not carry out any activities of enforcement, guarding, or handling prisoners. Instead, they handle activities such as maintenance and operation of kitchens and workshops' 56

In contrast to France or the UK, 'Australia has not had a long independent history of commercial involvement in its penal system since transportation ended and Australia was granted independence. Nevertheless, it was the second major penal estate after the USA to show interest in large-scale involvement in the recent wave of privatisation' ${ }^{57}$ In 1989 , Corrections Corporation of Australia was contracted to manage and operate the first private prison in Australia: Borallon Correctional Centre. ${ }^{58}$ Australia, despite having only nine contracted institutions out of a total of

\footnotetext{
${ }^{50}$ Rob Allen, 'Global Prison Trends 2015' (Penal Reform International, 2015) 24.

${ }^{51}$ van Zyl Smit and Dünkel (n 1) 288.

52 Manfred Nowak, Human Rights or Global Capitalism: The Limits of Privatization (University of Pennsylvania Press 2016) 126.

${ }^{53}$ ibid 127-28.

${ }^{54}$ Jonas Mueller-Töwe, 'Geheime Verträge, versteckte Kosten. Warum Private Dienstleister Deutchlands Gefängnisse nicht billiger, sondern teurer Machen, Correctiv (Correctiv, 12 November 2015) <https://correctiv.org/recherchen/stories/2015/11/12/teilprivatisierte-gefaengnisse-der-staat-zahlt-drauf/> accessed on 6 July 2018.

${ }_{55}^{55}$ Nowak (n 52) 127.

${ }^{56}$ Johannes Rieckmann, 'Privatization of Security Services: Comparing approaches to policing and prisons across the Atlantic' (American Institute for Contemporary German Studies, 5 June 2017) <https://www.aicgs.org/publication/privatization-of-security-services/> accessed on 6 July 2018.

${ }^{57}$ James Mehigan, and Abigail Rowe, 'Problematising prison privatisation: an overview of the debate' in Yvonne Jewkes, (ed.) Handbook on Prisons (Willan Publishing 2007) 363-64.

58 Joseph Sozzani, 'Privatisation in the United States and Australia: A Comparative Analysis of the Modern Privatisation Movement in Corrections', (2001) 13(1) Bond Law Review 136, 156.
} 
101 prison facilities, holds the largest share of privately incarcerated individuals in the world: ${ }^{59}$ $18.7 \% .^{60}$ Akin to Germany, prison administration and prison labour fall under the competence of Australian states and territories. ${ }^{61}$ Hence, while some prisons have adopted the 'wholesale' approach such as Ravenhall Prison in Victoria, ${ }^{62}$ other states have opted for a 'hybrid' system of service delivery more similar to the German and French examples, except that more services are outsourced. ${ }^{63}$

e) Private prison labour

Nonetheless, this article focuses on private prison labour, regardless of whether labour is undertaken in a private or publicly operated prison. As observed by Fenwick, along with prison privatization, private sector involvement in prison labour has increased considerably owing to the increasing costs of holding a continuously expanding penal population. ${ }^{64}$ In 1932, the ILO identified the different systems through which prison labour was arranged: the lease system, the special contract system, and the general contract system. ${ }^{65}$ Yet, a 1955 United Nations Report on prison labour 'denounced [the] lease and contract systems of prison labour as a violation of the Forced Labour Convention No. 29, but was lenient with regard to forms of (...) labour by prisoners for private employers' ${ }^{66}$ Furthermore, there are several manners by which private entities may be involved in prison labour. For instance, prisoners can work with a private entity 'as part of an education or training scheme to obtain qualifications, prisoners may work in workshops within the prison to produce goods which are sold to private entities in the open market, prisoners may work outside prison for a private entity as part of a pre-release scheme [and] prisoners may provide labour within prisons which contribute to the running of prisons run by private entities'. ${ }^{67}$

59 Colin Penter, 'The power of the corporate (private) prison industry' (The Stringer, 14 April 2014) <http://thestringer.com.au/the-power-of-the-corporate-private-prison-industry-and-why-australia-has-the-highestproportion-of-private-prisons-in-the-world-7189?cv=1> accessed on 15 July 2018.

${ }^{60}$ Productivity Commission for the Steering Committee for the Review of Government Service Provision, Report on Government Services 2017, (Volume C: Justice, 2017), Table 8A.4.

${ }^{61}$ Colin Fenwick, 'Private Benefit from Forced Prison Labour: Case studies on the application of Convention 29', Report to the International Confederation of Free Trade Unions (Centre for Employment and Labour Relations Law, University of Melbourne School of Law, 2000-2001) 19.

62 Jesuit Social Services (n 40) 6.

63 ibid.

${ }^{64}$ Colin Fenwick, 'When Privatization means exploitation: Prison labour in privatized facilities' in International Labour Organisation, Fundamental Rights at Work: Overview and Prospects (Labour Education 122(1) 2005) 40-43.

${ }^{65}$ See International Labour Organisation, 'Prison Labour I' (n 15) 319.

${ }^{66}$ Gerad De Jonge, 'Still Slaves of the State: Prison Labour and International Law' in Dirk van Zyl Smit and Frieder Dünkel, Prison Labour: Salvation or Slavery? (Ashgate Dartmouth 1999).

${ }^{67}$ International Labour Organisation, Report of the CEACR, Report III (Part 1A), ILC 89th Session, (2001), 39. 
However, on many occasions these arrangements led to conflicts with internationally-ratified norms.

\section{INTERNATIONAL STANDARD}

The next section identifies the requirements which signatories to the Convention must fulfil and demonstrates that, although prima facie incompatible with the norm, a system of privatised labour may be implemented, but carries additional requirements that must be adhered to. ${ }^{68}$ I intend to use these as indicators of good practice and identify which states' approach is to be preferred while developing a model framework. This area has received little attention in existing research and the law on this topic in many jurisdictions seems to be underdeveloped. ${ }^{69}$

\section{Forced Labour Convention (No. 29)}

The Forced Labour Convention (No. 29) is one of the eight fundamental conventions of the ILO. Having entered into force in 1932, the Convention is the most ratified by member states: 178, with a few exceptions such as the USA and China. The principal aim of the Convention is enshrined in its first provision by which parties to the Convention undertake 'to suppress the use of forced or compulsory labour in all its forms within the shortest possible period' ${ }^{70}$ Indeed, the Convention 'was adopted to develop the labour related aspects of the Slavery Convention' ${ }^{71}$ drawn by the League of Nations in 1926. In other words, the ILO conventions were initially conceived by the international community as a means to eradicate slavery. ${ }^{72}$ Under Article 2(1), forced or compulsory labour encompasses 'all work or service which is exacted from any person under the menace of any penalty and for which the said person has not offered himself voluntarily' ${ }^{73}$ Nevertheless, the ban is not absolute. The norm identifies five exceptions to the rule. ${ }^{74} \mathrm{We}$ focus upon the third exemption, Article 2(2)(c).

\section{Art. 2(2)(c)}

Under this provision, prison labour falls short of amounting to forced labour if imposed 'as a consequence of a conviction in a court of law, provided that the said work or service is carried out

\footnotetext{
68 ibid $47 \mathrm{ff}$.

${ }^{69}$ Lee Swepston, 'Prison Labour and International Human Rights' (2001) 52 Industrial Relations Research Association 359.

${ }^{70}$ Convention Concerning Forced or Compulsory Labour Convention, 1930 (No. 29) of the International Labour Organisation, Art.1(1).

${ }^{71}$ Swepston (n 69) 361.

72 Fenwick, 'Private Benefit from Forced Prison Labour' (n 61) 4.

${ }^{73}$ Forced Labour Convention (n 70) Art. 2(1).

74 ibid, Art. 2(2)(a)-(e).
} 
under the supervision and control of a public authority and that the said person is not hired to or placed at the disposal of private individuals, companies or associations' ${ }^{75}$ However, this does not exclude the practice from the concept of forced or compulsory labour. It was nonetheless built into the Convention as 'the benefits of exempting prison labour (...) were [directly or indirectly] in the interests of society in general'. ${ }^{76}$ One example would be where prisoners participate in public construction activities. ${ }^{77}$ Additionally, society derives an indirect benefit from the employment of prisoners, namely the prospect of rehabilitation, which ultimately contributes to the reduction of recidivism. Nonetheless, certain conditions must be satisfied in order to ensure compliance with the standard and to avoid exploitation. Interestingly, while the norm protects prisoners from forced labour for private benefit, it does not preclude their exploitation by the state.

\section{a) Conviction in a court of law}

Although straightforward, this requirement ensures that prison labour is only imposed where general principles of law such as the presumption of innocence and equality before the law are respected. ${ }^{78}$ While the wording of the provision prohibits prisoners awaiting trial to be placed under an obligation to perform labour, the Committee of Experts on the Application of Conventions and Recommendations (hereafter 'CEACR') has noted that the Convention itself does not preclude them from voluntarily taking part in work. ${ }^{79}$

\section{b) 'Supervision and control by a public authority'}

Secondly, prison labour must be supervised and controlled by a public authority. In instances where a private entity is involved in prison labour, compliance issues arise. Fenwick observes that this element serves a specific protective role. This is due to the fact that 'the inevitable focus of a private entity on its own business interests raises the prospect of a conflict with the reformative aims of the State' ${ }^{80}$ Thus, it seeks to ensure that rather than simply providing for private benefit, prison labour gives rise to a wider public benefit. ${ }^{81}$ Moreover, the CEACR has noted that, as prisoners do not enjoy the same rights as free workers, public authorities must exercise supervision and control in order to prevent private entities from determining the conditions of employment of

\footnotetext{
75 ibid, Art. 2(2)(c).

${ }^{76}$ International Labour Organisation, Report of the CEACR (n 67) 38.

77 ibid.

${ }^{78}$ International Labour Organisation, Eradication of Forced Labour: General Survey by the CEACR, Report III (Part 1B), ILC 96 ${ }^{\text {th }}$ Session, (2007) 26.

${ }^{79}$ International Labour Organisation, General Survey on the Reports concerning the Forced Labour Convention, 1930 (No. 29), and the Abolition of Forced Labour Convention, 1957 (No. 105), Report III, ILC 52nd Session, (1968) 211.

${ }^{80}$ Fenwick, 'Private Use of Prisoners Labour' (n 19) 270-71.

81 ibid.
} 
prisoners. ${ }^{82}$ In contrast to other requirements in the Convention, the CEACR has not so far identified any specific level of supervision or control. Nonetheless, the Committee has made clear that 'if the supervision and control are restricted to a public authority to inspect the premises periodically, this by itself would not appear to meet the requirements' ${ }^{83}$ Finally, the 'supervision and control must be effective, systematic, and regular and should be considered a matter for the services of government labour inspectors' ${ }^{84}$

\section{Requirements for prisoner employment by private means}

c) Penal labour privatisation

The end of the twentieth century was marked by developments in the penal systems of ILO member states that have had a significant impact upon the application of the Convention. Nowadays, private enterprises often employ--both inside and outside detention premises--prisoners housed in publicly-administered institutions, as well as employing those prisoners where the prison administration has been contracted to a private firm. ${ }^{85}$ Hence, a triangular nexus exists between the inmate, prison service, and the private company. ${ }^{86}$ Furthermore, the requirements of public supervision and control as well as that prisoners cannot be hired to or placed at the disposal of private entities apply independently and cumulatively. In other words, 'the fact that the prisoner remains at all times under the supervision and control of a public authority does not in itself dispense the government from fulfilling the second condition, namely that the person is not hired to or placed at the disposal of private individuals, companies or associations' ${ }^{87}$

\section{d) 'Hired to or placed at the disposal of'}

Implicitly, a compatibility issue arises with regard to private prisons. The CEACR has observed that 'in private prisons there are two inter-related forms of constraint: first, the private enterprise operating a prison includes prison labour in its profit calculations and, second, the private enterprise is not only a user of prison labour, but also exercises, in law or in practice, an important part of the authority which belongs to the prison administration' ${ }^{88}$ Nonetheless, several arguments have been advanced which suggest that a prisoner employed by a private entity (in any type of

\footnotetext{
${ }^{82}$ International Labour Organisation, Report of the CEACR, Report III (Part 1A), ILC 86th Session, (1998) 31.

83 ibid 32.

${ }^{84}$ International Labour Organisation, Eradication of Forced Labour (n 78) 65.

${ }^{85}$ International Labour Organisation, Giving Globalisation a Human Face: General Survey by the CEACR, Report III (Part 1B), (2012), 123.

${ }^{86}$ International Labour Organisation, Report of the CEACR (n 82) 31.

${ }^{87}$ International Labour Organisation, Report of the CEACR (n 67) 40.

${ }^{88}$ International Labour Organisation, Summary of Reports, Report III (Parts 1, 2 and 3), ILC 82nd Session, (1995), 90.
} 
arrangement), is never actually 'hired to or placed at the disposal' of such a body. For instance, a state representative argued that it is only in situations where the prisoner is 'employed by the private company (...) or where the prisoner was placed in a position of servitude in relation to the private company, but not where the performance of work was merely one of the conditions of imprisonment imposed by the state ${ }^{89}$ that he will be considered to have been hired to or placed at the disposal of a private company. Furthermore, an Employer member organisation opined that due to the atypical nature of such contractual arrangements, ${ }^{90}$ in which the state subsidises private contractors at an agreed per capita rate, ${ }^{91}$ they do not amount to a hiring arrangement and thus prisoners are not hired or placed at the disposal of private entities. This is further supported by the fact that no contractual agreement between the company and the prisoner exists. Finally, several governments maintain that private companies are limited by the rules set by the public authority and therefore, they do not enjoy 'absolute discretion over the type of work they could request the prisoner to do'. ${ }^{92}$ Yet, the CEACR disagrees, as 'the provisions of Article 2(2) (c) are not conditioned on any particular kind of legal relationship'. ${ }^{93}$ In other words, they apply regardless of whether such a relationship, in the form of a contract or other, exists between the private entity and the prisoner, which defeats the claims presented above. Overall, as will be explored, while the Convention prohibits forced labour for private profit or benefit, it does not preclude consensual prison labour for private profit or benefit. ${ }^{94}$

e) Private profit or benefit

The CEACR has observed that no condition precluding profit for private entities has ever been adduced. ${ }^{95}$ At the same time, the Committee opines 'the universal acceptance of the free-market principle might make obsolete legal requirements of a basic human rights Convention'. ${ }^{96}$ Therefore, although no strict prohibition exists, it is important for the anti-slavery norm to prevail over economic considerations. On the other hand, in my view, allowing private entities to derive profit from prison labour could exacerbate the risk of exploitation.

\section{Voluntariness}

\footnotetext{
${ }^{89}$ International Labour Organisation, Report of the CEACR (n 67) 31.

90 ibid.

${ }^{91}$ International Labour Organisation, Report of the CEACR (n 29) 95.

${ }^{92}$ International Labour Organisation, Report of the CEACR (n 67) 31.

${ }^{93}$ International Labour Organisation, Report of the CEACR (n 82) 31.

${ }^{94}$ International Labour Organisation, Summary Reports on Ratified Conventions, Report III (Part I), ILC 38th Session, (1955), 83.

95 International Labour Organisation, Report of the CEACR (n 29) 96.

96 ibid 96.
} 
Fenwick explains that 'more than permitting voluntary labour, however, Convention 29 positively requires that prison labour for the benefit of private interests must be performed voluntarily'. ${ }^{97}$ The Committee has identified two requirements that must be satisfied so as to ensure voluntariness on part of the prisoner: freely given consent and the conditions under which prisoners perform labour must 'approximate a free labour relationship'. ${ }^{98}$

a) Freely given informed consent

With regard to consent, a difficult question arises: 'whether prisoners, notwithstanding their captive circumstances, can be in a situation of truly voluntary labour, for which they have offered themselves voluntarily and without the menace of any penalty, including the loss of a right or a privilege, so that their work does not come under the definition of forced or compulsory labour' ${ }^{99}$ This requirement seeks to protect prisoners from exploitation since 'prison labour is captive labour in the full sense of the term, namely, in contrast to temporary workers these workers have no access, in law and in practice, to employment outside the prison environment. Indeed, in most cases their work is covered by no labour law whatsoever'. ${ }^{100}$ Furthermore, as mentioned, it is important that labour remains a real choice and not one in which refusal would give rise to any detriment for prisoners such as 'remaining confined in their cells for unreasonably long periods, having no alternative to boredom, or being disadvantaged in any early release programme because of failure to undertake work'. ${ }^{101}$ Thus, the Committee opined that given the captive circumstances of prisoners, formal consent should be in writing. ${ }^{102}$ Still, such a requirement is not sufficient on its own terms. 'The most reliable and overt indicator of voluntariness can be gleaned from the circumstances and conditions under which the labour is performed and whether those conditions approximate a free employment relationship'. ${ }^{103}$

\section{b) 'Conditions approximating a free labour relationship'}

The CEACR considers that prison labour for the benefit of private interests is only compatible with the Convention where consent is given freely by those persons involved 'as well as further guarantees and safeguards covering the essential elements of a labour relationship, such as the level of wages, the extent of social security, and the application of regulations on safety and

\footnotetext{
${ }^{97}$ Fenwick, 'Private Benefit from Forced Prison Labour' (n 61) 14.

${ }^{98}$ International Labour Organisation, Report of the CEACR (n 67) 44.

${ }^{99}$ International Labour Organisation, Eradication of Forced Labour (n 78) 29.

${ }^{100}$ International Labour Organisation, Report of the CEACR (n 82) 31.

${ }^{101}$ International Labour Organisation, Report of the CEACR (n 67) 43.

${ }^{102}$ International Labour Organisation, Eradication of Forced Labour (n 78) 65.

${ }^{103}$ International Labour Organisation, Report of the CEACR (n 67) 44.
} 
health'. ${ }^{104}$ Yet, how far should these conditions resemble those of free workers? 'If normal labour law were to apply, this might imply that all conditions of work, including wages, social security, safety and health and labour inspection comparable to those prevailing on the free labour market would be required'. ${ }^{105}$ However, despite the fact that differences in terms of wages and social security are acceptable, no variation as regards occupational safety and health is allowed. ${ }^{106}$ Certain deductions 'are sometimes said to be justified on the basis that there is lower productivity of prison labour; or (...) because [prisoners] carry out work at much lower cost which would otherwise not be economically feasible' ${ }^{107}$ In addition, their wages may be used to compensate victims along with alimony or other relevant obligations. ${ }^{108}$ Finally, deductions are made for the board and lodging ${ }^{109}$ of prisoners. Nonetheless, the CEACR has stated that although these conditions do not have to mirror the conditions applicable in a free labour relationship, they 'should not be so disproportionately lower than the free market that it could be characterised as exploitative'. ${ }^{110}$ Though imprecise, this requirement seeks to establish a benchmark so as to determine whether particular arrangements are abusive. In undertaking such an assessment, the abovementioned conditions must be 'weighed together with the circumstances under which formal consent has been given in order to ascertain whether the Convention is being respected when private entities are involved with prison labour'. ${ }^{111}$

\section{5. 'Meaningful' work}

Although not part of the Convention, a condition requiring prison services to provide 'meaningful' labour should be inserted. In addition to the requirements that the CEACR has identified, such an obligation would help 'guard against the risk that private business goals (...) conflict with the reformative purpose of prisoners' labour'. ${ }^{112}$ Indeed, prison labour ought to be undertaken due to its rehabilitative and reintegrative effect. However, not all employment will serve these purposes. The addition of 'meaningful', 'purposeful' or 'useful' work is thus necessary. It is to be interpreted as employment that imparts 'employment skills and habits to prisoners (...) [as well as] social and

\footnotetext{
${ }^{104}$ International Labour Organisation, Report of the CEACR, Report III (Part 1A), ILC 106th Session, (2017), 252.

${ }^{105}$ International Labour Organisation, Report of the CEACR (n 67) 46.

${ }^{106}$ International Labour Organisation, Eradication of Forced Labour (n 78) 65-66.

${ }^{107}$ International Labour Organisation, Report of the CEACR (n 67) 46.

108 ibid 46.

109 ibid.

${ }^{110}$ International Labour Organisation, Report of the CEACR (n 67) 47.

111 ibid.

${ }^{112}$ International Labour Organisation, Fundamental Rights at Work: Overview and Prospects (n 64) 277.
} 
personal competence'. ${ }^{113}$ If prisoners are subjected to work programs that provide little rehabilitative value, 'they will have no incentive to participate actively in the work program and develop good work habits'. ${ }^{114}$ Hence, 'meaningful work' could potentially help reduce recidivism as well as protect prisoners from exploitation. Nonetheless, although preferable, meaningful work, or 'real work' in the words of the Howard League for Penal Reform, if provided by businesses, 'must make profit'. ${ }^{115}$ In consequence, it will not always be straightforward to offer them such employment.

\section{THE CASES OF FRANCE, GERMANY, AND AUSTRALIA}

In delegating prison management or entrusting certain correctional functions to the private sector, France, Germany, and Australia could find themselves at odds with the Convention. In fact, their models differ, and all have been subject to comments by the ILO regarding compliance. This section seeks to identify institutional differences with the objective of discerning the preferred approach and establishing a model framework. Given the limited space for discussion, I will focus on the most contentious safeguards.

\section{Requirements}

a) Supervision and control by a public authority

In France, prisoners undertaking labour are monitored by supervisors, whose role is to ensure that disciplinary and health and safety rules are complied with. ${ }^{116}$ Where prisoners are working for private companies, the supervisors are employees of the latter, and are accredited by the Interregional Director of Prison Services. ${ }^{117}$ A 1999 government circular regulating the relations between the labour inspection services and the prison administration, contains several provisions governing prison inspections. ${ }^{118}$ The Labour Inspectorate within the Ministry of Labour has a narrow power to carry out inspections. ${ }^{119}$ In fact, the director of a penitentiary must ensure each year that regular inspections take place and following the inspection, the officials must

\footnotetext{
113 Phelan (n 26) 1758.

114 ibid.

115 The Howard League for Penal Reform, 'Business Behind Bars Making Real Work in Prison Work' (London, 2011), 12.

${ }^{116}$ Code de Procédure Pénale, Art. D433-5.

117 ibid.

118 Caroline Mandy, L'inspection du travail en prison, Direction Régionale des Entreprises, de la Concurrence, de la Consommoation, du Travail et de l'Emploi (Bordeaux, December 2017), 2.

${ }^{119}$ Code de Procédure Pénale, Art. D433-8.
} 
communicate their findings to the prison administration, who must respond within two months. ${ }^{120}$ However, in contrast to the 'free labour market', its powers are limited to the fields of hygiene and security in the workplace ${ }^{121}$ and it is the director of the penitentiary who must invite the inspectors. ${ }^{122}$ The circular and legislation are silent as to a possibility of self-referral and thus the inspectors' ability to intervene is more that of advice than that of supervision and control. Nonetheless, with regard to private enterprises, the inspector will communicate his or her findings to the enterprise itself and the prison director may then impose an injunction on it. ${ }^{123}$ Thus, while the CEACR has not clarified the level of public supervision and control required, and the powers of the labour inspectorate are limited, France has an oversight mechanism in place to avoid more obvious forms of exploitation. Yet, civil servants are not entrusted with the task of supervising private prison labour.

In Germany, the situation is somewhat different. Although the German and French models of prison privatisation are virtually identical in other respects, 'the staff of the private enterprise (...) [has] the right to issue work related instructions [but] the supervision of prisoners and all decisions related to inmate treatment remain the responsibility of the penal enforcement authority' ${ }^{124}$ In addition, the CEACR recognised that in Germany, 'prisoners remain at all times under the authority and control of the prison administration' 125 as 'when work is carried out for private companies in prisons, only the material for the work is brought into the prison by the companies, the supervision of the prisoners concerned being the sole responsibility of the prison staff', ${ }^{126}$ corresponding to the special contract system of prison labour. ${ }^{127}$ Furthermore, 'prison workshops may be investigated by the [Länder's] own inspectors or by mutual accident insurance association inspectors'. ${ }^{128}$ Accordingly, it may observed that Germany's supervisory regime is compatible with the Convention and ensures that work performed by prisoners is always supervised by public officials.

${ }^{120}$ Laure Anelli and Cécile Marcel, 'Inspecteur du travail en prison: un pouvoir limité' (Dedans-Dehors 14 February 2018) <https://blogs.mediapart.fr/observatoire-international-des-prisons-section-francaise/blog/140218/inspecteurdu-travail-en-prison-un-pouvoir-limite> accessed on 15 July 2018.

${ }^{121}$ Code de Procédure Pénale, Art. D433-5.

${ }^{122}$ Anelli and Marcel (n 120).

${ }^{123}$ Mandy (n 118) 2.

${ }^{124}$ International Labour Organisation, Report of the CEACR (n 104) 198.

${ }^{125}$ International Labour Organisation, Report of the CEACR, Report III (Part 1A), ILC 101st Session, (2012), 262.

${ }^{126}$ International Labour Organisation, Report of the CEACR, Report III (Part 1A), ILC 98th Session, (2009), 214.

${ }^{127}$ International Labour Organisation, 'Prison Labour I' (n 15) 319.

${ }^{128}$ International Labour Organisation, Extension of the Labour Inspection Convention, (1947) (No. 81), to activities in the non-commercial services sector, Report VI (1), ILC 82nd Session, (1995), 17. 
In contrast, Australia has pursued a significantly different path. Since it is the competence of individual states to regulate their respective prison administrations, they have not followed the same path. For instance, in South Australia, the Correctional Services Act 1982 limits the extent to which correctional functions may be delegated to private enterprises, leaving the Department of Corrective Services ('DCS') in charge of non-delegable functions. Consequently, the DCS employs two-unit supervisors 'that form part of the organisational structure of G4S', ${ }^{129}$ the entity managing Mount Gambier Prison. Also, a contract compliance officer appointed by the state works on site and ensures that the contractual terms are complied with. ${ }^{130}$ Conversely, other states such as Victoria, which have opted for the 'wholesale' approach to prison privatisation, find themselves at odds with the Convention as the CEACR has observed that the norm 'does not allow full delegation of supervision or control to a private business' ${ }^{131}$ Under this model, the management of the institution is arranged under the conditions set in the contract between the public authority and private entity. The Australian government has argued that because the private entity manages the institution on its behalf, regulated by a contract, ${ }^{132}$ and the fact that an Ombudsman, an Auditor General and the Office of Correctional Services Review scrutinise private prisons, ${ }^{133}$ prisoners in private prisons are under 'the supervision' of a public authority. Furthermore, Australia maintains that since 'the private sector has no rights in relation to establishing conditions for the work of prisoners'; ${ }^{134}$ the entity in question does not control their work. Accordingly, although some form of supervision and control exists, it can be characterised as weak, especially as prison management contracts are not usually publicly available, ${ }^{135}$ which it is submitted is an unsatisfactory arrangement.

\section{b) 'Hired to or placed at the disposal of'}

The triangular relationship described above arises in all the jurisdictions that allow the employment of prisoners by private bodies. It means that once a contractual agreement is reached between the outside firm and the government, prisoners will be 'hired to' it.

\footnotetext{
129 Jane Andrew, Max Baker and Philip Roberts, Prison Privatisation in Australia: The State of the Nation, (University of Sydney 2016) 31.

130 ibid 32.

${ }^{131}$ International Labour Organisation, Report of the CEACR, Report III (Part 1A), ILC 87th Session, (1999), 109.

132 ibid.

133 Andrew, Baker and Roberts (n 129) 40.

${ }^{134}$ International Labour Organisation, Report of the CEACR, Report III (Part 1A), ILC 99th Session, (2010), 222.

135 Andrew, Baker and Roberts (n 129) 4.
} 
In France, prison labour is performed in three ways: general service work, work for the Industrial Board of Prison Establishments, and the hiring of prison labour by private enterprises. ${ }^{136}$ With regard to the latter, 'the labour relationship between the detainee and the enterprise using the labour or responsible for the work function do not give rise to an employment contract, as the enterprise is deprived of a large proportion of the rights and obligations incumbent on the employer, particularly in terms of recruitment and dismissal, assignment and de-assignment being carried out by public officials'. ${ }^{137}$ Yet, Article 33 of the Prison Act 2009 stipulates that the participation of prisoners in work activities should be covered by a work engagement form, signed by both the prison administration and the prisoner, ${ }^{138}$ but not the contractor. The document 'specifies matters such as hiring, the duration of work, remuneration, trial periods, conditions relating to the suspension and termination of the labour relationship and requirements relating to regular attendance ${ }^{\prime 139}$ with the objective of recognising 'the prisoner as a labour rights' bearer' 140 in accordance with the principle of resocialisation. The French government has not contested the fact that prisoners working for private interests are 'hired to' the private entity, as they maintain that work 'is not exacted under the menace of any penalty from a person who has not offered himself voluntarily for that work' ${ }^{141}$ and hence this situation does not fall under the remit of the Standard. In spite of this, France remains in contravention of this condition.

Prisoners employed by private entities in Germany may be divided into two groups, 'with some enjoying the full benefit of a free employment relationship, while others were hired to those who use their labour, without their consent'. ${ }^{142}$ The CEACR has observed that the special contract system of prison labour employed in Germany conflicts with the Convention, as prisoners are 'hired to' private entities. ${ }^{143}$ In the Committee's view, a prisoner is 'typically hired to an undertaking where there is no contractual relationship between the two, while a contract exists between the undertaking and the penal institution under which the penal institution is paid the price of the labour it provides to the undertaking, ${ }^{144}$ which is the case in Germany's system, clearly

\footnotetext{
136 International Labour Organisation (n 29) 125.

${ }^{137}$ International Labour Organisation, Report of the CEACR, Report III (Part 4A), ILC 83rd Session, (1996), 81-82.

${ }^{138}$ Loi n ${ }^{\circ}$ 2009-1436 Pénitentiaire du 24 Novembre (1).

${ }^{139}$ International Labour Organisation, Direct Request by the CEACR on C29, (France), ILC 99th Session, (2009).

${ }^{140}$ International Labour Organisation, Direct Request by the CEACR on C29, (France), ILC 101st Session, (2011).

${ }^{141}$ International Labour Organisation, Report of the CEACR (n 137) 79.

142 International Labour Organisation, Report of the CEACR, Report III (Part 1A), ILC 92nd Session, (2004), 132133.

${ }^{143}$ International Labour Organisation, Report of the CEACR (n 126) 215.

${ }^{144}$ International Labour Organisation, Report of the CEACR, Report III (Part 1A), ILC 85th Session, (1997), 80.
} 
violating the standard. Unlike France, there is no obligation for the prison service to draw up a work engagement form for prisoners taking up employment in Germany. Yet, in most Länder, an obligation to work remains in place.

Australia's situation is somewhat distinct. As mentioned, in some states, private entities manage prisons entirely. However, in contrast to Germany and France, the Australian government makes several arguments to the effect that the arrangements in place surrounding the hiring or placing of prisoners at the disposal of private entities are compatible with the Convention. The government believes that prisoners 'are not hired to or placed at the disposal of private individuals, companies or associations, since their legal custody has not been transferred to a private provider of prison services, and sentenced prisoners remain in the legal custody of the Secretary to the Department of Justice (Victoria) or the Chief Executive of the Department of Correctional Services (South Australia) until they are released from prison'. ${ }^{145}$ Secondly, Australia considers that since the private entities employing prisoners have no rights to determine the conditions of work, prisoners do not find themselves in a situation of complete servitude and are thus not 'placed at the disposal of' anyone. ${ }^{146}$ Finally, Australia further contends that as the labour relationship between the private entity and the prisoner is not covered by an employment contract, a prisoner cannot be 'hired to' a private employer. The CEACR has nonetheless rejected these arguments, as the Convention requirement precluding prisoners from being 'hired to or placed at the disposal' of private entities is meant to cover 'situations where the companies do not have absolute discretion over the type of work they can request the prisoner to do'. ${ }^{147}$ Moreover, it is irrelevant that no direct contractual relationship between a private sector employer and the prisoner exists; it will suffice that 'a prisoner is made available as a worker to the private sector, even pursuant to a triangular labour hire arrangement'. ${ }^{148}$ Consequently, the practice in Australia also exceeds the limits set by the norm.

\section{Voluntariness}

'The Committee has acknowledged that where work is performed under conditions approximating those of a free labour relationship, namely with the consent of the prisoner and accompanied by a

\footnotetext{
${ }^{145}$ International Labour Organisation, Giving Globalisation a Human Face (n 85) 247.

${ }^{146}$ International Labour Organisation, Report of the CEACR (n 67) 31.

${ }^{147}$ International Labour Organisation, Giving Globalisation a Human Face (n 85) 247.

${ }^{148}$ Fenwick, 'Private Use of Prisoners Labour' (n 19) 275.
} 
number of guarantees, [the hiring of prisoners or their placement at the disposal of private entities] may be compatible with the Convention'. ${ }^{149}$

\section{a) Freely given informed consent}

Since 1987, work is no longer treated as an obligation but rather as a right in French prisons. ${ }^{150}$ Prisoners may request that work may be made available to them. The subsequent Prison Act of $2009^{151}$ does nonetheless place 'all convicted persons under the obligation to carry out at least one of the activities offered to them by the head of the establishment and the director of the Prison Probation and Reintegration Service'. ${ }^{152}$ On the other hand, 'the refusal to take up a post offered does not in itself constitute a disciplinary offence', ${ }^{153}$ but one could doubt the voluntariness of such labour.

In Germany, under the Execution of Sentences Act 1976, prisoners must consent to their employment by private entities. However, this provision was suspended by the later 1981 Act in order to 'improve the budget structure'. ${ }^{154}$ In consequence, as the Länder have competence over penal enforcement in their jurisdictions since 2006, some have adopted their own regulations, while other states follow the Federal Prison Act under which labour is compulsory. Out of the sixteen Länder, work remains an obligation in twelve and save for three, prisoners can be assigned to workshops operated by private entities. ${ }^{155}$ Unfortunately, 'prisoners who fail to work may lose their claim to remission or may face disadvantages when the decision about release is considered [ultimately amounting to an] indirect form of compulsion', ${ }^{156}$ that could potentially lead to exploitation.

The CEACR has made several observations concerning individual Australian states. In New South Wales, employment is voluntary ${ }^{157}$ and 'to ensure that the informed consent of prisoners to work for private companies is obtained, (...) an inmate wishing to apply for work must complete a form, sign it and present it to the Industry manager'. ${ }^{158}$ Moreover, in Western Australia, although prison labour is compulsory under s.95(4) of the Prisons Act 1981, the state claims that

\footnotetext{
${ }^{149}$ International Labour Organisation, Direct Request by the CEACR on C29 (n 139).

${ }^{150}$ Loi n ${ }^{\circ} 87-432$ du 22 Juin 1987 relative au Service Public Pénitentiaire.

${ }^{151}$ Loi n²009-1436 Pénitentiaire du 24 Novembre, s. 27.

${ }^{152}$ International Labour Organisation, Direct Request by the CEACR on C29 (n 140).

${ }^{153}$ International Labour Organisation, Direct Request by the CEACR on C29 (n 139).

${ }^{154}$ International Labour Organisation, Report of the CEACR (n 104) 198.

155 ibid.

156 van Zyl Smit and Dünkel (n 1) 831-32.

${ }^{157}$ Crimes (Administration of Sentences) Act 1999 (NSW), s.6(1).

${ }^{158}$ International Labour Organisation, Report of the CEACR, Report III (Part 1A), ILC 104th Session, (2014), 141.
} 
the provision 'has not been enforced and prisoners have not been forced to participate in work programmes'. ${ }^{159}$ Yet, s.69(b) of the same act makes it an offence to not properly undertake work, thus 'exacting labour under the menace of a penalty' in violation of the standard. Finally, in both Queensland and South Australia, work is compulsory. ${ }^{160}$ In the former, the CEACR has noted 'although no formal consent of prisoners is required, the work programme is a voluntary initiative (...) [and] there are no consequences for a prisoner for refusal to participate', ${ }^{161}$ while in the latter, prisoners in the only private institution (Mount Gambier), apply in writing for work opportunities. ${ }^{162}$ Consequently, in these circumstances, only the practice in Western Australia expressly circumvents the requirement of informed consent.

\section{b) Conditions approximating a free labour relationship}

The Australian government has argued that 'under Convention 29, no requirement that conditions approximating a free employment relationship are necessary to ensure the consent of prisoners to work', ${ }^{163}$ accusing the CEACR of acting ultra vires and seemingly rejecting the concept of normalisation. To avoid the exploitation of a captive workforce and to facilitate their rehabilitation, 'their formal consent to work needs to be authenticated by arm's length conditions of employment approximating those accepted by workers having access to the free labour market'. ${ }^{164}$

\section{i) Wages}

In France, s.32 of the Prison Act 2009 stipulates that all wages cannot be lower than the hourly rate fixed by Decree No. 2010-1635 at 45\% of the minimum wage (SMIC), ${ }^{165}$ which it is submitted is an adequate benchmark. In respect of activities carried out pursuant to a labour hiring contract or in 'semi privées' institutions, a minimum remuneration (SMR) must be respected. ${ }^{166}$ However, the latter does not provide a minimum guaranteed remuneration as, although it is set by the administration, 'the SMR [is] reached by dividing the total wages by the number of hours worked, [thus amounting] to an average collective minimum remuneration'. ${ }^{167}$ As a consequence,

\footnotetext{
159 ibid.

${ }^{160}$ Corrective Services Act 2006, s.66 (Queensland); Correctional Services Act 1982, s.29(1) (SA).

${ }^{161}$ International Labour Organisation, Report of the CEACR (n 158).

162 ibid.

${ }^{163}$ International Labour Organisation, Report of the CEACR (n 29) 177.

164 ibid 98.

${ }^{165}$ International Labour Organisation, Direct Request by the CEACR on C29, (France), ILC 104th Session, (2014).

${ }^{166}$ International Labour Organisation, Direct Request by the CEACR on C29 (n 140).

167 ibid.
} 
'prisoners work on average 30 hours a week' ${ }^{168}$ and are paid an average of $€ 3.97$ an hour, ${ }^{169}$ namely $€ 120$ per week.

Prisoner wages in German prisons have also caused controversy. Although the CEACR has previously observed that the remuneration level, 'set at 9 per cent of the average wage of workers and employees covered by the old-age insurance scheme [was not sufficient], (...) the draft legislation to raise the benchmark wage to 15 per cent of the reference value could not be passed due to the resistance of the Länder'. ${ }^{170}$ Therefore, 'German inmates work longer hours: 38.5 hours per week for a salary of ${ }^{\prime 171} € 62,{ }^{172}$ which may be characterised as being 'disproportionately lower than free-market wages' and hence exploitative.

While France and Germany attempt to develop policies in accordance with the principle of normalisation, Australia has previously argued 'it is completely unrealistic to suggest or expect that inmates might be remunerated in accord with open market remuneration conditions'. ${ }^{173}$ Besides, information concerning prisoner remuneration in some states is lacking ${ }^{174}$ and the Australian government has failed to provide the CEACR with detailed wage levels for several years. Nonetheless, from the available information, we see that prisoners working in private prisons in Victoria are paid between $\$ 5.5$ and $\$ 8.25$ per day in contrast to $\$ 75$ for employees on the free labour market. ${ }^{175}$ In Queensland, 'levels of remuneration range from $\$ 2.04$ per day to $\$ 3.99$ per day for unskilled to skilled positions (...) [with] an overall ceiling of \$55.86 per week' ${ }^{176}$ The fact that wage levels are disproportionately lower than on the free market renders the labour relationship exploitative and once again leaves Australia in violation of the norm, and in a worse position vis-à-vis Germany.

ii) Social security

According to Article D366 of the French Code of Criminal Procedure, prisoners benefit from the French social security system in the same manner as other workers, 'with the sole

\footnotetext{
168 Shea (n 20) 12.

${ }^{169}$ International Labour Organisation, Direct Request by the CEACR on C29 (n 140).

${ }^{170}$ International Labour Organisation, Report of the CEACR (n 142) 133.

${ }^{171}$ Shea (n 20) 12.

172 Rachel Knaebel, 'Prison workers in Germany are organising' (Equal Times, 2 March 2015) <https://www.equaltimes.org/prison-workers-in-germany-are\#.VPWBnfmsWCk> accessed on 25 July 2018.

${ }^{173}$ International Labour Organisation, Report of the CEACR (n 142) 123.

${ }^{174}$ Information concerning the wage levels of prisoners in SA and NSW was not transmitted.

175 International Labour Organisation, Report of the CEACR (n 29) 100.

176 ibid 101.
} 
exception of unemployment benefits'. ${ }^{177}$ Their remuneration is 'subject to employers' and workers' contributions (...) for sickness, maternity and old-age insurance'. ${ }^{178}$ German prisoners enjoy similar social protections 'to those in France with the difference that German prison workers are covered by unemployment insurance but are excluded from the pension scheme'. ${ }^{179}$ Finally, in most common law jurisdictions employed prisoners are not considered employees. ${ }^{180}$ However, the information relating to the extent of social security covering prisoners in Australia is missing from this study. Nonetheless, Fenwick has observed that in Australia 'the duty of care owed to the prisoner was held to be analogous to that of the duty of employer to employee' ${ }^{181}$ hence providing some form of protection. Thus, as social security does not have to mirror that of outside workers, France and Germany seem to provide a satisfactory social security cover as opposed to that in Australia.

\section{Occupational safety and health}

In accordance with CEACR comments, all three jurisdictions in question provide for safety and health conditions analogous to those in a free employment relationship, given its nonderogable status. French legislation ${ }^{182}$ specifies that 'the safety and health measures provided in the Labour Code (...) shall be applicable to work performed by detainees within and outside prison establishments ${ }^{183}$ and employed prisoners have the right to compensation for accidents and occupational diseases. ${ }^{184}$ In German institutions, 'the statutory safety and health and accident prevention provisions are also fully applied' 185 without restriction. In Australia, the Standard Guidelines for Corrections in Australia 2012 require - under Article 4.50 - that occupational health and safety standards applying in the community should apply to prison labour. ${ }^{186}$ All three jurisdictions have successfully adopted this requirement.

a) 'Meaningful' work

\footnotetext{
177 Shea (n 20) 12.

${ }^{178}$ International Labour Organisation, Report of the CEACR (n 29) 126.

${ }^{179}$ Shea (n 20) 12.

${ }^{180}$ Pullin v Prisoner Commissioners [1957] 1 WLR 1186 (UK); State of New South Wales v Napier [2002] NSWCA 402 (Australia).

${ }^{181}$ Fenwick, 'Regulating Prisoners' Labour in Australia' (n 23) 29.

182 Code of Criminal Procedure, Art. D109, as amended by Decree No. 981099 of 8 December 1998; Code of Social Security, Arts.D412-36 to 412-71.

${ }^{183}$ International Labour Organisation, Report of the CEACR (n 29) 126.

184 ibid.

${ }^{185}$ International Labour Organisation, Report of the CEACR (n 126) 215.

${ }^{186}$ Fenwick, Regulating Prisoners' Labour in Australia' (n 23) 18.
} 
The European Prison Observatory maintains that in French penitentiaries, the work available is straightforward, monotonous and 'it is extremely rare that the work available (...) will give prisoners the opportunity to develop any specific and valued skill'. ${ }^{187}$ The information concerning the nature of employment opportunities in Germany and Australia is out of date and thus most likely inaccurate, but usually, prisoners undertake carpentry, printing or any processing work. ${ }^{188}$ As was pointed out to me during an interview with an ILO official, while work that imparts skills is a first step to avoid recidivism, it does not guarantee the prisoners' successful reintegration into society. The process of rehabilitation through work should not stop at the end of a prisoner's sentence, but ideally, the prison service should be thinking beyond the gate. ${ }^{189}$

\section{E. 'CONVENTION 29: A FLOOR, NOT A CEILING'}

As observed in the above analysis, since the three jurisdictions in question have implemented distinct models of prison and prison labour privatisation, compliance with the Forced Labour Convention varies according to the respective requirements. This section evaluates the current practices in France, Germany, and Australia and sets out a model framework compatible with international law that protects prisoners from exploitation and favours social reinsertion. While the Forced Labour Convention prohibits prisoners from being supervised, controlled, hired to, or placed at the disposal of private interests when engaged in compulsory labour, it allows these arrangements so long as labour is voluntary. Nonetheless, from a human rights point of view, as free and informed consent is difficult to obtain given the captive circumstances of prisoners, an approach requiring compliance with all the above conditions would better serve the objective of the Convention: avoiding the exploitation of a vulnerable workforce. It is worth noting that the CEACR has identified minimum requirements rather than an exhaustive list. In other words, the norm is a floor and not a ceiling.

\section{Classification}

In order to evaluate the approaches, I group the Convention requirements into the following categories: accountability, safeguards, and conditions of employment. Accountability

\footnotetext{
187 Marie Crétenot and Barbara Liaras, 'Prison Conditions in France' in European Prison Observatory, Detention Conditions in the European Union (Paris 2013) 28.

188 European Social Fund, Prison Work in Europe: Organisation and Management of Prison Workshops, (Centre D’Iniciatives per a la Reinsercio 2007) 85.

${ }^{189}$ See Rowena Mason, ‘John Timpson's workshops at Wandsworth Prison help inmates learn a trade' (The Telegraph, 31 May 2010) <https://www.telegraph.co.uk/finance/jobs/john-timpson/7790842/John-Timpsons-workshops-atWandsworth-Prison-help-inmates-learn-a-trade.html> accessed on 29 July 2018.
} 
encompasses the prison privatization models and the requirement of public supervision and control. Secondly, the safeguards include the prisoner's consent and the prohibition of hiring them to or placing them at the disposal of private entities. Finally, prisoner wages, social security, occupational safety and health and meaningful work form parts of the conditions of employment.

\section{a) Accountability}

In terms of accountability, it is clear that prison and prison labour privatisation pose an issue given that 'private actors are insulated from the public and not subject to the same political controls as are government actors'. ${ }^{190}$ To preserve some form of accountability in this context, it is necessary to have a level of public control. Firstly, with regard to the prison privatisation models adopted by the jurisdictions in question, namely the 'wholesale' privatisation and 'semi-privées' institutions, the latter system is 'more acceptable from a human rights perspective, as the major sovereign power of using force to uphold public order and security in the prison remains with the State'. ${ }^{191}$ Consequently, it is submitted that the special contract system is the most adequate. Secondly, concerning public supervision and control of prison labour, only Germany abides by the standard, given that France and Australia have delegated the supervisory task to the entity providing labour to prisoners. Hence, although some form of public supervision and inspection exists in France, the fact that the labour inspectorate's powers are constrained to occupational health and safety measures and that inspections must be requested by the prison director, heavily undermines public accountability and hinders transparency. Nevertheless, the system of prison and prison labour privatisation in certain Australian states seems to be the least favourable of all since the management of some prisons has been fully entrusted to the private sector, few inspection powers exist, and contractual secrecy prevails.

Intuitively, it would be counterproductive to insulate employment in prisons from society, especially as the idea of 'conditions approximating a free labour relationship' is already embedded in the Convention itself as a requirement for compliance. We should also not forget that some of the products produced, packed or assembled within the walls of our prisons end up back in society. This may seem to be obvious, but it can serve as an important reminder that prisons form an active part of our world. For these reasons, in developing a system of privatised prison labour, the German approach should be mirrored in terms of public accountability and direct supervision.

\footnotetext{
${ }^{190}$ Logan (n 31) 194.

${ }^{191}$ Nowak (n 52) 130.
} 


\section{b) Safeguards}

The prohibition on hiring or placing a prisoner at the disposal of private entities and the necessity to obtain prisoners' consent to employment serve as safeguards against exploitation and servitude. However, although no jurisdiction places prisoners at the complete disposal of private entities, none has devised a system in which prisoners are not 'hired to' private enterprises due to the way states have contracted prison labour management (triangular relationship). It could nonetheless be argued that since modern penal policy must ensure that prison life reflects free society as closely as possible, this requirement is outdated and there already is sufficient protection against exploitation in that prisoners cannot be 'placed at the disposal of' private entities and the subsequent conditions. Regardless, the 'work engagement form' requirement adopted in France should be followed as it serves a protective role and helps to accustom prisoners to 'normal' contracts of employment. Thus, although conformity has not yet been fully achieved by any state, the French approach seems to be moving in the right direction. Moreover, Germany has previously been subject to comments at the International Labour Conference and was found to be in violation of this condition, ${ }^{192}$ and has set out to make changes progressively. In contrast, Australia does seem to have resisted a change in this regard even though the CEACR has rejected the arguments presented and therefore, once again, Australia is the lowest performer in this regard.

Secondly, concerning freely given informed consent, France, New South Wales, Queensland and South Australia ensure that prisoners take on employment voluntarily and without the threat of any penalties. Informed consent ensures that work is treated as a right rather than an obligation and shields prisoners from exploitation, and thus its significance cannot be understated. While the German approach is the most suitable concerning accountability, most Länder compel prisoners to employment or penalise them for refusing to work. In this respect, Germany has the least appropriate system in the area of prisoners' consent. In my view, in terms of safeguards, France has created the most comprehensive system. Ideally, any future system of private prison labour should not allow the prison service 'to hire' (as understood under the Convention) prisoners to private employers. They should ensure that prisoners are covered by a contractual relationship with the latter, and furthermore, must allow prisoners to have a choice of whether to engage in prison labour, especially when working for private interests.

\footnotetext{
192 International Labour Organisation, Observations and Information Concerning Particular Countries (Part 2), ILC 90th Session (2002).
} 


\section{c) Conditions of employment}

Finally, as discussed above, the employment conditions guarantee that work is genuinely voluntary as imprisonment may hinder informed consent. France has adopted the most suitable conditions approximating a free labour relationship. In terms of wages, a prisoner's salary in France is not disproportionately lower than the free market; whereas in Germany and Australia, prisoner wages are so low that those labour relationships would be characterised as exploitative per the Convention. While Australia has not provided enough information in terms of social security, the French and German conditions of employment are adequate. Concerning occupational safety and health, the practices in all jurisdictions are satisfactory. Finally, as described, meaningful work is vital to the process of rehabilitation and social reinsertion; yet, from the information gathered in this study, all states have failed to accommodate such opportunities. Hence, in an ideal system, prisoners should be paid similar wages at the statutory minimum wage, and social security provisions should be analogous to the French system where prisoners are entitled to the same protections as workers in free employment relationships, statutory health and safety standards must apply and work that imparts transferrable skills should be provided. Furthermore, having set out to achieve the objectives of the Convention, states should apply the principle of normalisation through the measures that are to be taken.

\section{F. CONCLUSION}

In summary, although France, Germany, and Australia do not fully comply with the Convention, it is necessary to resist a purely legalistic approach to the issue, as the reasons for turning to the private sector deserve further consideration. In most cases, privatisation was undertaken to alleviate overcrowding, increase the number of inmates employed with the objectives to curb reoffending, reduce incarceration costs and to improve prison conditions.

This article does not argue that there is no alternative to the current private prison labour arrangements, but rather that, since many states have found no alternative solution to the issues, they should at least develop their systems in accordance with international standards. The model identified could serve as a guide to compliance with the Convention while taking an approach favourable to rehabilitation. In the identified model: a state should adopt the 'semi-privée' institution model, have public officials supervise prison labour, allow for frequent labour inspections, ensure that prisoners are not 'hired to' private employers, provide a contract of 
employment, require a prisoner's free and informed consent to work, and provide for employment conditions that resemble those in a free labour relationship as closely as possible.

For now, however, although deficient in some respects, the French system is the most capable of protecting prisoners from exploitation and the closest to the model identified. While this model does not solve a number of issues discussed in the article, unlike the current systems, it proposes a model compatible with the Forced Labour Convention having rehabilitation as a main objective. Although private sector involvement in correction may be a viable temporary solution, the moral, economic, legal and social consequences seem to outweigh the benefits where a state has built its system based on the 'wholesale approach' to prison privatisation.

Along with the creation of financial interests in the growth of the prison population and making prison labour available as a source of cheap labour, penal populism has also contributed to the perception that there are no alternatives to prison and prison labour management. Private providers of corrections services seem to be under the impression that due to fiscal deficits on part of governments, further business opportunities will arise in the future. ${ }^{193}$ Yet, it remains to be asked whether states should question the practicability and efficiency of prison regulation by contract in light of the recent failures on part of private contractors, ${ }^{194}$ and what exploitative prison labour practices can lead to. ${ }^{195}$

\footnotetext{
${ }^{193}$ Stephen Nathan, 'Overview of prison privatisation' (Annual Conference EPSU prison services network, Athens, 2011) 2 .

194 Jessica Elgot, 'MoJ seizes control of Birmingham Prison from G4S' (The Guardian, 20 August 2018) $<$ https://www.theguardian.com/business/2018/aug/20/moj-seizes-control-of-birmingham-prison-from-g4s> accessed on 21 August 2018.

${ }^{195}$ Ed Pilkington, 'US Inmates stage nationwide prison labour strike over modern slavery' (The Guardian, 21 August 2018) <https://www.theguardian.com/us-news/2018/aug/20/prison-labor-protest-america-jailhouse-lawyers-speak> accessed on 26 August 2018.
} 